\title{
Repeatability of growth characteristics and wood properties for solid wood production from Euca- lyptus camaldulensis half-sib families growing in Thailand
}

\author{
Ikumi Nezu', Futoshi Ishiguri ${ }^{*}$, Haruna Aiso², Sapit Diloksumpun ${ }^{3}$, Jyunichi Ohshima ${ }^{1}$, Kazuya \\ lizuka' ${ }^{1}$, Shinso Yokota'

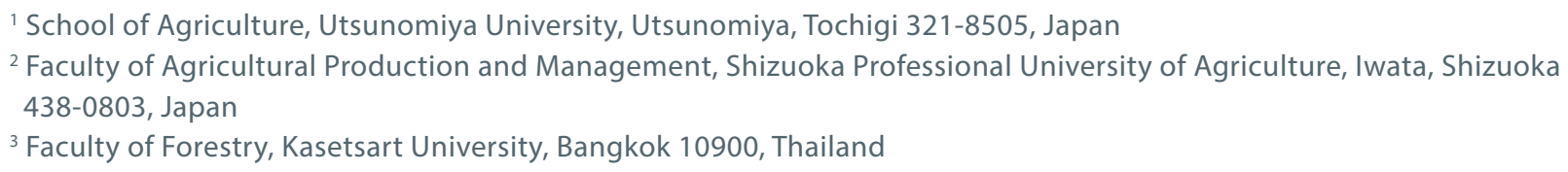 \\ *Corresponding author: Futoshi Ishiguri, E-mail: ishiguri@cc.utsunomiya-u.ac.jp
}

\begin{abstract}
To promote solid wood production, the diameter at breast height, height, stress-wave velocity, surface-released strain, basic density and compressive strength parallel to the grain were measured for 10 half-sib families of 12-year-old Eucalyptus camaldulensis Dehnh. trees growing in Thailand. Based on the results, growth rates, correlations among measured properties, radial and among-family variations of wood properties, and their repeatability were evaluated. Diameter at breast height, height, and wood volume were exponentially increased at initial stage, and then gradually increased toward to 12 years after planting. The maximum current annual increment and mean annual increment in wood volume showed at age of 8 and 11years old, suggesting that rotation period for optimum productivity may be ranged from 8 to 11 years old. Wood with stable properties was found greater than $6 \mathrm{~cm}$ from the pith. These results indicate that 12-year-old E. camaldulensis trees had already reached the maturation stage. No significant correlations were found between growth characteristics and wood properties. Significant variances in the height, stresswave velocity, and basic density were found among the 10 families. The $F$-values and repeatability of the wood properties in the outer wood were higher than those in the inner wood. These results indicate that the properties of the outer wood are closely related to genetic factors. Thus, to obtain superior $E$. camaldulensis trees for solid wood production, the family selection should be conducted using the outer wood of aged trees.
\end{abstract}

Keywords: Growth rate; radial variation; among-family variation; stress-wave velocity; basic density; compressive strength parallel to the grain

\section{Introduction}

Eucalyptus camaldulensis Dehnh. is a fast-growing tree species (Hillis and Brown, 1984). Eucalyptus camaldulensis has been extensively planted in the area from the tropics to the subtropics (Ishizuka, 1996). Whilst selected this species genetic material can exhibit notable tolerances for various environmental and biological stressors, such tolerances, adaptive traits and growth vigour are not ubiquitous throughout the species. (Thomson et al, 2018).

In Thailand, wood produced from this species with a short rotation period (4 to 5 years) is mainly used for pulpwood. To increase the yield and pulp quality, improvements in plantation management and tree breeding programs have been conducted for E. camaldulensis in Thailand (Pinyopusarerk et al., 1996; Veenin et al., 2005; Yodnam et al., 2010; Sungtong and Diloksumpun, 2011; Ishiguri et al., 2013; Kuramochi et al., 2014; Aiso-Sanada et al., 2019). Yodnam et al. (2010) investigated narrow-sense heritability of growth and physiological characteristics for 24-month-old E. camaldulensis. They reported that narrow-sense heritability for the diameter at breast height and height showed higher values compared to those in other characteristics, suggesting that the influence of genetics on growth characteristics were larger than physiological characteristics. Kuramochi et al. (2014) found significant differences in the growth characteristics, Pilodyn penetration, and basic 
density $2 \mathrm{~cm}$ from the bark in 5-year-old E. camaldulensis trees among 15 families. In addition, no significant correlations were found between the wood properties related to pulpwood quality and growth characteristics, which suggests that these two traits were independent of each other (Kuramochi et al., 2014). Thus, families with both superior growth characteristics and wood properties related to pulpwood quality can be selected for this species.

Pulpwood from fast-growing species is not always dealt at higher price. Conversely, the availability of solid wood has been considered for many fast-growing species, including Eucalyptus species (Iwasaki et al., 2012). In a previous study, we evaluated the wood properties of 4-year-old E. camaldulensis half-sib families selected based on their superior growth characteristics (Ishiguri et al., 2013, 2017). Significant among-family variances were identified in the stem diameter, Young's modulus of logs, moisture content, basic density, and maximum height of the interlocked grain (Ishiguri et al., 2013, 2017). No significant correlations were found between the diameter at breast height and solid wood properties, such as the dynamic Young's modulus of logs, moisture content, basic density, and shrinkage (Ishiguri et al., 2013, 2017). Therefore, families with superior growth characteristics and these solid wood properties are possible for the families already selected by superior growth characteristics. However, for solid wood production, wood from aged larger-diameter trees is generally needed compared to pulp and paper production, because if lumber with $10 \mathrm{~cm}$ in width will produce, at least $14 \mathrm{~cm}$ in bud-end diameter logs is needed. The available information on the wood properties and estimates of the narrow-sense heritability and/ or broad-sense heritability (repeatability) of E. camaldulensis trees are mainly for young trees, while the information on aged trees of this species is minimal.

The present study aimed to clarify the growth characteristics and wood properties for solid wood from aged E. camaldulensis half-sib families of 12-year-old E. camaldulensis growing in a progeny test site in Thailand. Based on the results, we clarified genetic factors related to the measured properties and correlations among the measured properties.

\section{Materials and Methods}

\section{Progeny test site}

The progeny test site of second generation E. camaldulensis trees located in Wang Nam Khiao, Nakhon Ratchasima, Thailand $\left(14^{\circ} 30^{\prime} \mathrm{N}, 101^{\circ} 56^{\prime} \mathrm{E}, 320 \mathrm{~m}\right.$ above sea level) was used in the present study. The study site was previously deforested area and later reforested with commercial trees such as E. camaldulensis since 1995. Most physical and chemical soil properties were not significantly different from nearby natural forest where the soils were sandy loam to sandy clay loam soils with very strong acid (Yodnam et al., 2010). The test site was established in 2006 using 120 half-sib families selected as plus trees from first generation progeny trail originally from 23 provenances and 5 regions in Australia and the selection from Thailand based on their growth characteristics (Table 1). The 120 half-sib families used in the second generation progeny trial established in Thailand were selected from the 1st generation trials established in four locations in Thailand. Although E. camaldulensis has several subspecies (Butcher et al. 2009), but actual taxonomic identities of each family used in the present study were unknown. A latinized row-column design with eight replications was applied and each replicated block consisting of three trees per family per sub-block was spaced with $3.0 \times$ $1.5 \mathrm{~m}$ and randomly located using CycDesigN (Williams et al., 2002). A thinning treatment was conducted in 2010 , resulting in that only one tree per family per sub-block remained in July 2011 (Kuramochi et al., 2014).

\section{Growth characteristics and wood properties}

The mean diameter at breast height and height of 120 families in this progeny test site were $14.8 \pm 2.7 \mathrm{~cm}$ and $18.0 \pm 2.1 \mathrm{~m}$, respectively. A total of 30 trees from 10 families were selected from 120 half-sib families according to similar radial growth (Table 2). The diameter at breast height, height, and stresswave velocity of the stem were measured in May 2018. The diameter at breast height and height were measured by a diameter tape and an ultrasound height meter (Vertex IV, Haglöf), respectively. In addition, stem volume was calculated by the formula proposed by Kamo et al. (1990). The stress-wave velocity of the stem was measured between 0.5 and $1.5 \mathrm{~m}$ above the ground by a stress-wave timer (Fakopp Microsecond Timer, Fakopp Enterprise) according to a previous method (Ishiguri et al., 2012). The surface-released strain was measured at two positions of a circumference at $1.3 \mathrm{~m}$ above the ground in each tree by a strain gauge method (Sasaki et al., 1978; Okuyama et al., 1981). After removing the bark of the measuring position (3 $\times 4 \mathrm{~cm}$ ), a strain gauge (KFGS-2-120-C1-5, Kyowa) was attached to the surface of the xylem in the longitudinal direction using cyanoacrylate adhesive (CC-35, Kyowa). The surface stress was released by cutting the upper and lower sides of the strain gauge using a handsaw, and then, the surface-released strain was measured by a strain meter (DBU-120A, Kyowa).

Two pith-to-bark core samples $5 \mathrm{~mm}$ in diameter were collected from $1.3 \mathrm{~m}$ above the ground with an increment borer (Haglöf) to measure the basic density and compressive strength parallel to the grain under green condition (Matsumoto et al., 2008; Ishiguri et al., 2012; Wahyudi et al., 2015). One core sample in each tree was cut into small segments at $1-\mathrm{cm}$ intervals from the pith to measure the radial variations in the basic density. The basic density was calculated by dividing the oven-dry weight by the green volume determined by the water displacement method.

Another core sample was cut into small segments at 5-mm intervals from the pith to measure the radial variations in the compressive strength parallel to the grain under green condition. The compressive strength was measured using a core testing machine (Fractometer II, IML) (Ishiguri et al., 2012). The specimen was clamped in the testing machine, and then, a load was slowly applied in the longitudinal direction. The compressive strength of each specimen was recorded by the testing machine. 
Table 1

Regions and provenances of E. camaldulensis used in the second-generation progeny test (modified from Sungtong and Diloksumpun, 2011).

\begin{tabular}{|c|c|c|}
\hline Region & Provenance & Family \\
\hline \multirow[t]{11}{*}{ Petford Region, QLD } & Eccles creek/tributaries & $1,7,11,12,13,15,16,17,18, \underline{19}, 22,23,24,25,26$ \\
\hline & Eureka creek/tributaries Mishap creek & $33,35,50,51,52,54,56,57,58,60, \underline{61}, 62,112$ \\
\hline & Mishap creek & $39,44,47$ \\
\hline & Hales siding & $64,65,67,68,69$ \\
\hline & Petford bridge & $\underline{71}, 72,144$ \\
\hline & Emuford & $76,79,80,81,99$ \\
\hline & Montalbion & $84,85,87,88,94,96$ \\
\hline & Headwaters-emu creek & $104,106,107$ \\
\hline & Headwaters-emureka creek & 109 \\
\hline & Walsh river-W. emu creek junction & $114,115,119,126,127$ \\
\hline & Flat rock pool & $129, \underline{130}, 135,137,139$ \\
\hline \multirow[t]{6}{*}{ Walsh-Mitchell River, QLD } & Petford bridge & $145,149,150,154,155,156,158$ \\
\hline & Walsh river rockwood & 162,163 \\
\hline & Mt. Mulgrave & $164,166,170$ \\
\hline & Palmeryville & $172,174,176,177,178,179,180,181$ \\
\hline & Lynd junction & $182,183,184,186$ \\
\hline & Healeys yard & $187, \underline{188}, 191,192,193,196,198,199,201,203$ \\
\hline \multirow{4}{*}{$\begin{array}{l}\text { Northern Territor, Western Australia, } \\
\text { and other QLD }\end{array}$} & Katherine & $\underline{208}$ \\
\hline & Lannard river & 209 \\
\hline & Kennedy river & $211,217,218,219$ \\
\hline & Morehead river & $224,225, \underline{226}, \underline{227}, 228,229$ \\
\hline \multirow[t]{2}{*}{ Thailand } & Thai selection & $\underline{232}, 234, \underline{236}, 244,246$ \\
\hline & Thailand race (control) & $991,992,995,996,997$ \\
\hline
\end{tabular}

Note: Family numbers with underline were selected for the present study according to similar radial growth. The mean diameter at breast height and height of 120 families were $14.8 \pm 2.7 \mathrm{~cm}$ and $18.0 \pm 2.1 \mathrm{~m}$, respectively.

Table 2

The growth characteristics and wood properties of 30 trees from 10 families.

\begin{tabular}{|c|c|c|c|c|c|c|c|c|}
\hline Family No. & $n$ & $\begin{array}{l}\mathrm{DBH} \\
(\mathrm{cm})\end{array}$ & $\begin{array}{l}\mathrm{H} \\
(\mathrm{m})\end{array}$ & $\begin{array}{c}V \\
\left(m^{3}\right)\end{array}$ & $\begin{array}{l}\text { SWV } \\
(\mathrm{km} / \mathrm{s})\end{array}$ & $\begin{array}{l}\text { RS } \\
(\%)\end{array}$ & $\begin{array}{c}\mathrm{BD} \\
\left(\mathrm{g} / \mathrm{cm}^{3}\right)\end{array}$ & $\begin{array}{c}\mathrm{CS} \\
(\mathrm{MPa})\end{array}$ \\
\hline 19 & 3 & 19.6 & 20.8 & 0.280 & 3.34 & -0.043 & 0.61 & 41.8 \\
\hline 61 & 3 & 17.9 & 20.5 & 0.230 & 3.50 & -0.050 & 0.61 & 39.2 \\
\hline 71 & 3 & 18.1 & 20.9 & 0.240 & 3.37 & -0.082 & 0.61 & 36.5 \\
\hline 130 & 3 & 18.3 & 20.5 & 0.243 & 3.46 & -0.064 & 0.58 & 36.7 \\
\hline 188 & 3 & 17.6 & 19.5 & 0.214 & 3.43 & -0.037 & 0.63 & 39.1 \\
\hline 208 & 3 & 17.4 & 18.2 & 0.197 & 3.71 & -0.056 & 0.68 & 41.9 \\
\hline 226 & 3 & 19.8 & 19.4 & 0.267 & 3.38 & -0.052 & 0.63 & 41.0 \\
\hline 227 & 3 & 17.0 & 18.6 & 0.190 & 3.59 & -0.059 & 0.62 & 41.9 \\
\hline 232 & 3 & 18.2 & 22.0 & 0.254 & 3.11 & -0.057 & 0.65 & 39.9 \\
\hline 236 & 3 & 17.2 & 21.0 & 0.220 & 3.54 & -0.045 & 0.61 & 48.9 \\
\hline Mean/total & 30 & 18.1 & 20.1 & 0.233 & 3.44 & -0.054 & 0.62 & 39.1 \\
\hline$F$-value & & $1.081^{\mathrm{ns}}$ & $2.467^{*}$ & $1.139^{\text {ns }}$ & $2.838^{*}$ & $1.194^{\mathrm{ns}}$ & $2.657^{*}$ & $1.502^{\text {ns }}$ \\
\hline$R$ & & 0.03 & 0.33 & 0.04 & 0.38 & 0.06 & 0.36 & 0.14 \\
\hline
\end{tabular}

Note: $n$, number of trees; $\mathrm{DBH}$, diameter at breast height; $\mathrm{H}$, height; $\mathrm{V}$, wood volume; SWV, stress-wave velocity; $\mathrm{RS}$, surface-released strain; $\mathrm{BD}$, basic density; $\mathrm{CS}$, compressive strength parallel to the grain under green condition; $R$, repeatability; ${ }^{*}$, significance at the $5 \%$ level; ns, no significance. 


\section{Statistical analysis}

The sigmoidal regression curves were fitted to growth characteristics and wood volume. The rotation period for optimum productivity was determined from the age of the maximum current annual increment (CAI) or maximum mean annual increment (MAl) from the sigmoidal regression curve (Pohjonen and Pukkala, 1994; Liao et al., 2003). The inflection point in the sigmoidal regression curve was defined as maximum CAI (Liao et al., 2003).

The mean values of the growth characteristics and wood properties for each family were calculated by averaging the values obtained from the pith to the bark in each tree. Amongfamily variations in the growth characteristics and wood properties were determined by analyses of variance (ANOVA). The repeatability of growth characteristics and wood properties in families was estimated using the following formula (Nakagawa and Schielzeth, 2010):

$$
R=\delta_{f}^{2} /\left[\delta_{f}^{2}+\delta_{e}^{2}\right]
$$

where $R$ is repeatability, $\delta_{f}^{2}$ is the family variance component, and $\delta_{e}^{2}$ is the residual variance component. The mean value for each family was also calculated at each $1 \mathrm{~cm}$ position to clarify radial variations in the wood properties. Furthermore, Pearson's correlation analysis was performed to clarify the relationships among the measured properties. All statistical analyses were performed using the $\mathrm{R}$ statistical software package version 3.4.1 (R Development Core Team, 2017).

\section{Results}

The mean values of the diameter at breast height, height, wood volume, stress-wave velocity, surface-released strain, basic density, and compressive strength parallel to the grain under green condition in all 30 trees were $18.1 \mathrm{~cm}, 20.1 \mathrm{~m}$, $0.233 \mathrm{~m}^{3}, 3.44 \mathrm{~km} / \mathrm{s},-0.054 \%, 0.62 \mathrm{~g} / \mathrm{cm}^{3}$, and $39.1 \mathrm{MPa}$, respectively (Table 2).

Diameter at breast height, height, and wood volume were exponentially increased at initial stage and then these growth gradually slow down toward to 12 years after planting (Figure 1). The age showing maximum CAI was 4,3 , and 8 years old for diameter at breast height, height, and wood volume, respectively (Figure 1). The MAI of wood volume reached to peak at age 11. On the other hand, the peaks of MAI in diameter at breast height and height showed first year after planting, and then decreased toward 12 years old (Figure 1).

Both the basic density and the compressive strength increased from the pith to approximately $6 \mathrm{~cm}$ from the pith and then remained almost constant toward the bark (Figure 2). From these radial profiles, the wood was classified into two positions to clarify the family and residual variances and relationships of the inner and outer wood properties: 1) wood with unstable wood properties (pith to $3 \mathrm{~cm}$ from the pith, inner wood) and 2) wood with stable properties (6 to $8 \mathrm{~cm}$ from the pith, outer wood).
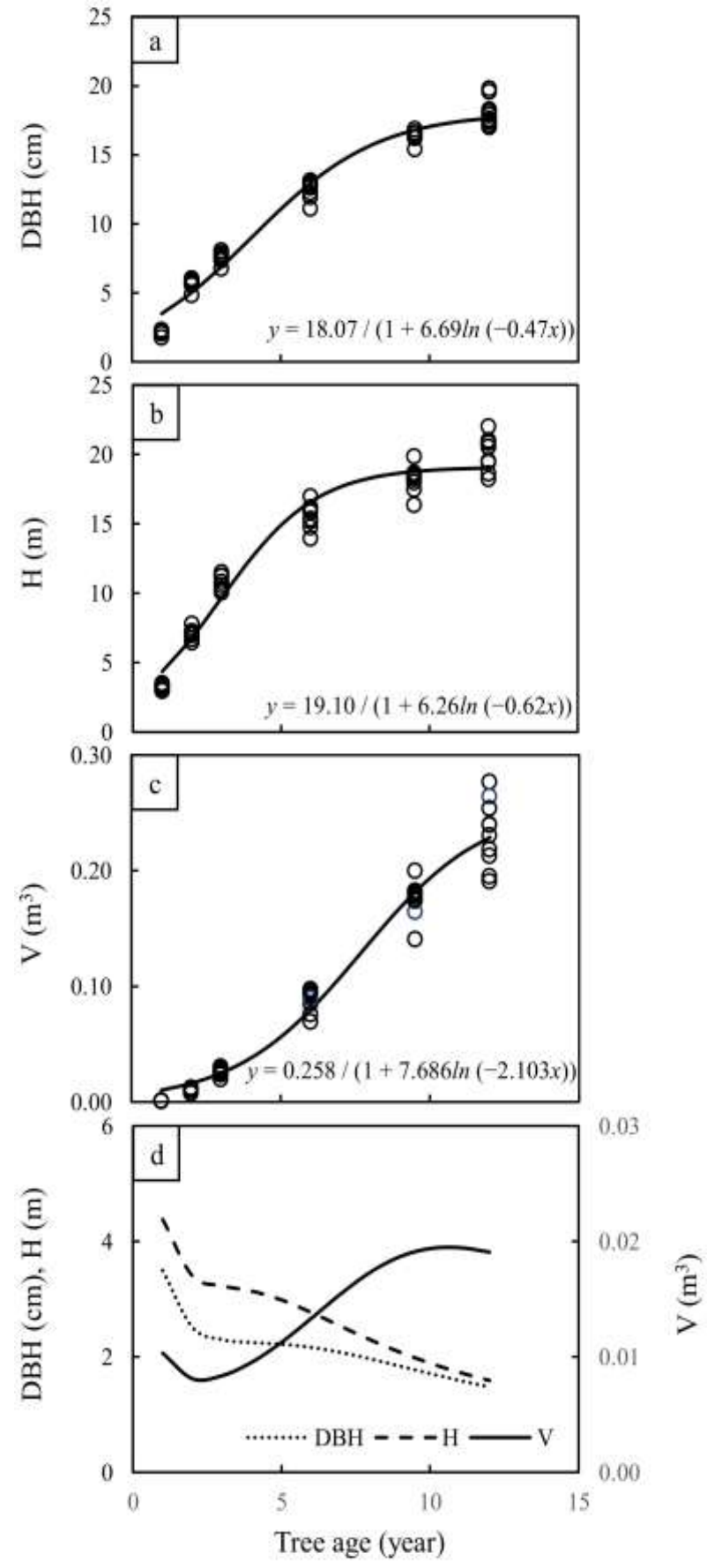

Figure 1

Logistic curves (a-c) and curves of mean annual increment (MAI) (d) for diameter at breast height (DBH), height (H), and wood volume (V).

Note: Each circle in graphs a-c indicates the mean value of each family. Curves were fitted using the logistic function.

Each curve in graph dindicates the MAI of the mean value of each family.

No significant correlations were observed among the growth characteristics and wood properties (Table 3). For the compressive strength parallel to the grain, a significant correlation was found between the inner and outer wood. In contrast, there was no significant correlation in the basic density between the inner and outer wood (Figure 3). 
Significant differences in the height, stress-wave velocity, and basic density were found among families (Table 2). The repeatability of the diameter at breast height, height, wood volume, stress-wave velocity, surface-released strain, basic density, and compressive strength were $0.03,0.33,0.04,0.38$, $0.06,0.36$, and 0.14 , respectively (Table 2 ). The repeatability values observed for the wood properties were larger than those of the diameter at breast height and wood volume. The repeatability of the basic density and compressive strength were 0.02 and -0.16 for the inner wood and 0.46 and 0.42 for the outer wood, respectively (Table 4), and thus, the values in the outer wood were higher than those in the inner wood.
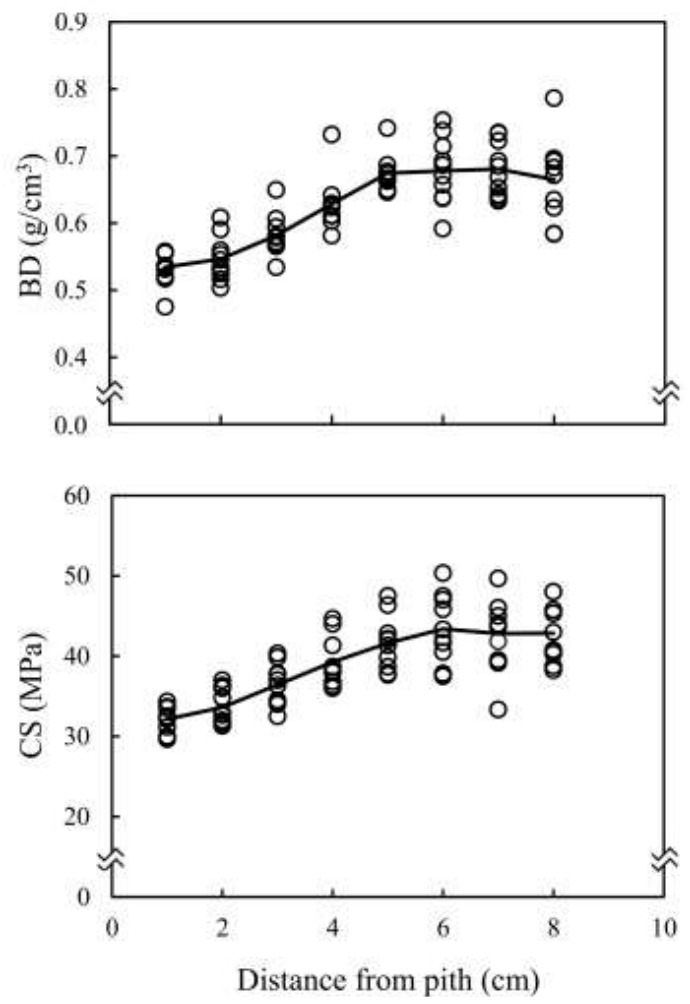

Figure 2

Radial variations in the basic density (BD) and compressive strength (CS) parallel to the grain under green condition in 10 families.

Note: Open circles and solid lines indicate the values of individuals and mean values of the 10 families, respectively.

\section{Table 3}

The correlation coefficients between the growth characteristics and wood properties of 30 trees from 10 families.

\begin{tabular}{lll}
\hline & DBH & $H$ \\
\hline SWV & $-0.273 n s$ & $-0.142 \mathrm{~ns}$ \\
RS & $-0.237 n s$ & $-0.123 \mathrm{~ns}$ \\
BD & $-0.014 \mathrm{~ns}$ & $-0.245 \mathrm{~ns}$ \\
CS & $-0.196 \mathrm{~ns}$ & $-0.217 \mathrm{~ns}$
\end{tabular}

Note: $\mathrm{DBH}$, diameter at breast height; $\mathrm{H}$, height; SWV, stress-wave velocity; RS, surface-released strain; $\mathrm{BD}$, basic density; $\mathrm{CS}$, compressive strength parallel to the grain under green condition; ns, no significance. Used data, mean values from 30 trees.
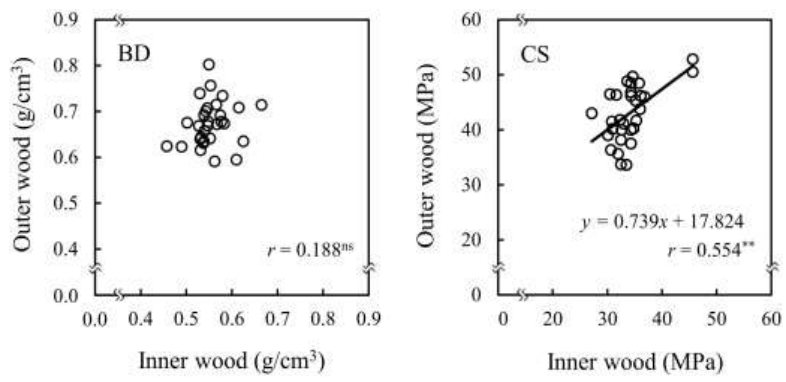

Figure 3

The correlation coefficients $(r)$ between inner and outer wood properties of 30 trees from 10 families.

Note: Inner wood, pith to $3 \mathrm{~cm}$ from the pith; outer wood, 6 to $8 \mathrm{~cm}$ from the pith. Used data, mean values of inner and outer wood from 30 trees. BD, basic density; CS, compressive strength parallel to the grain under green condition; ${ }^{* *}$, significance at the $1 \%$ level; ns, no significance.

Table 4

The $F$-value and repeatability $(R)$ for inner and outer wood of 30 trees from 10 families.

\begin{tabular}{|c|c|c|c|c|c|}
\hline Radial position & Traits & $\delta_{f}^{2}$ & $\delta_{e}^{2}$ & $F$-value & $R$ \\
\hline \multirow{2}{*}{ Inner wood } & $\mathrm{BD}$ & $0.03 \times 10^{-3}$ & $1.67 \times 10^{-3}$ & $1.061^{\mathrm{ns}}$ & 0.02 \\
\hline & CS & -2.27 & 16.6 & $0.591^{\mathrm{ns}}$ & -0.16 \\
\hline \multirow{2}{*}{ Outer wood } & $\mathrm{BD}$ & $1.13 \times 10^{-3}$ & $1.34 \times 10^{-3}$ & $3.534^{* *}$ & 0.46 \\
\hline & CS & 11.0 & 15.4 & $3.151^{*}$ & 0.42 \\
\hline \multicolumn{6}{|c|}{$\begin{array}{l}\text { Note: Inner wood, pith to } 3 \mathrm{~cm} \text { from the pith; outer wood, } 6 \text { to } 8 \mathrm{~cm} \text { from the } \\
\text { pith; BD, basic density; CS, compressive strength parallel to the grain under } \\
\text { green condition; } \delta^{2} \text {, variance component of family; } \delta^{2}{ }_{e^{\prime}} \text { variance component of } \\
\text { residual; }{ }^{* *} \text {, significance at the } 1 \% \text { level; }{ }^{*} \text {, significance at the } 5 \% \text { level; ns, no } \\
\text { significance. }\end{array}$} \\
\hline
\end{tabular}

\section{Discussion}

\section{Growth characteristics}

In general, the stem growth rates in trees show sigmoidal growth; growth in the initial stage is exponential and then stabilizes with maturation (Liao et al., 2003). In the present study, the diameter at breast height, height and wood volume increased after planting, and then became stable values toward 12 years (Figure 1). The age of the inflection point in sigmoidal regression curves was 4,3 , and 8 years old for diameter at breast height, height, and wood volume, respectively. The MAI of wood volume was increased from 1 to 11 years old and then decreased, while those of diameter at breast height and height showed a peak at first years after planting and then decreased until at age 12 (Figure 1). Pohjonen and Pukkala (1994) examined the suitable rotation period for E. camaldulensis plantation in Northeast Thailand based on the age of maximum MAI of stocking volume. They reported that the optimum rotation period should be set 12 years for the spacing of $3 \times 3$ and $2 \times 4$ $\mathrm{m}$ without thinning. The result of age showing maximum MAI in wood volume in the present study is shorter than the 
optimum rotation age reported by Pohjonen and Pukkala (1994). Based on the results of maximum CAl and MAI of wood volume, the rotation age for plantation of this species in Thailand should be 8 to 11 years for efficient solid wood production.

\section{Wood properties}

The mean values of stress-wave velocity in the present study was $3.44 \mathrm{~km} / \mathrm{s}$ (Table 2). Several researchers have measured the stress-wave velocity of stems in Eucalyptus species at an age of approximately 10 years old or older (Blackburn et al., 2010; Wahyudi et al., 2015; Prasetyo et al., 2017). Blackburn et al. (2010) reported that the stress-wave velocity of the stem ranged from 3.18 to $3.36 \mathrm{~km} / \mathrm{s}$ in 14-year-old $E$. nitens trees planted in Australia. In 9-year-old E. urophylla, E. grandis, and E. pellita trees grown in Indonesia, the stress-wave velocity were 3.18, 3.15 , and $3.35 \mathrm{~km} / \mathrm{s}$, respectively (Prasetyo et al., 2017). Wahyudi et al. (2015) reported that the stress-wave velocity of 26-year-old E. alba trees planted in Indonesia was $3.23 \mathrm{~km} / \mathrm{s}$. The mean value in the present study $(3.44 \mathrm{~km} / \mathrm{s}$, Table 2$)$ was similar to the values obtained in other Eucalyptus species by other researchers.

The mean surface-released strain obtained here was $-0.054 \%$ (Table 2). Kojima et al. (2009b) reported that the mean values of surface-released strain were $0.096 \%$ and $-0.073 \%$ for 11-year-old E. globulus and 14-year-old E. grandis trees planted in Australia, respectively. For 23 to 26-year-old E. signata, E. andreana, E. piperita, and E. haemastoma trees planted in Japan, the mean values of surface-released strain were -0.093 , $-0.093,-0.102$, and $-0.077 \%$, respectively (Hirohashi et al., 2012). The mean surface-released strain obtained in the present study was relatively smaller than the values of other Eucalyptus species at a similar or older tree age.

The basic density obtained in the present study was 0.62 $\mathrm{g} / \mathrm{cm}^{3}$ (Table 2). In 9-year-old E. camaldulensis trees grown in Thailand, the basic density was $0.66 \mathrm{~g} / \mathrm{cm}^{3}$ (Veenin et al., 2005). For 9-year-old E. urophylla, E. grandis, and E. pellita trees planted in Indonesia, the mean values of the basic density were $0.46,0.41$, and $0.46 \mathrm{~g} / \mathrm{cm}^{3}$, respectively (Prasetyo et al., 2017). Dickson et al. (2003) reported that the basic density of 25 -yearold E. dunnii trees planted in Vietnam was $0.60 \mathrm{~g} / \mathrm{cm}^{3}$. The basic density obtained in the present study was similar to that in 9-year-old E. camaldulensis trees (Veenin et al., 2005), whereas it was relatively higher than the values for three other 9-yearold Eucalyptus species (Prasetyo et al., 2017) and 25-year-old E. dunnii trees (Dickson et al., 2003).

In the present study, compressive strength under green condition was $39.1 \mathrm{MPa}$ (Table 2). Wahyudi et al. (2015) reported that the mean values of the compressive strength parallel to the grain in pith-to-bark core samples under green condition ranged from 25.3 to $39.0 \mathrm{MPa}$ in 26-year-old E. alba trees. In E. grandis, E. nitens, and E. saligna trees grown in Australia (unknown age), the compressive strength parallel to the grain in small clear specimens under green condition were 38.7-43.4, 31.1-34.5, and 34.6-38.6 MPa, respectively (Hillis and Brown, 1984). Our result for the compressive strength under green condition was similar to those in other Eucalyptus species reported by other researchers.

These results indicate that the properties of wood from 12-year-old E. camaldulensis trees in Thailand are not inferior to the properties of wood from other Eucalyptus species that are 10 years old or older. In addition, from the results for the surface-released strain, the frequency of warp and crack of the lumber was relatively lower than that in other Eucalyptus species when the solid lumber was produced from 12-year-old $E$. camaldulensis trees.

\section{Radial variations in wood properties}

In the present study, the basic density and the compressive strength increased from the pith to $6 \mathrm{~cm}$ from the pith and then became stable (Figure 2). Many researchers have reported radial variations in the wood properties of Eucalyptus species (Bamber et al., 1982; Wilkes, 1984; Ohbayashi and Shiokura, 1990; Jorge et al., 2000; Prasetyo et al., 2017, 2019). Jorge et al. (2000) reported that the wood fiber length significantly increased from the pith to the bark in 12 to 15 -year-old E. globulus trees. In 4-year-old E. saligna trees, the oven-dry density and vessel element length increased from the pith to the bark, and the wood fiber length increased from the pith to 4 to $5 \mathrm{~cm}$ from the pith and then stabilized (Ohbayashi and Shiokura, 1990). All radial variations in E. camaldulensis trees investigated here (Figure 2) showed similar radial patterns to those in other Eucalyptus species; the wood properties values increased from the pith to the bark.

Discussions about xylem maturation have been conducted on many tropical tree species, including Eucalyptus species (Bao et al., 2001; Honjo et al., 2005; Kojima et al., 2009a; Ishiguri et al., 2012; Wahyudi et al., 2015). Based on the results of radial variations in the wood fiber length, Kojima et al. (2009a) reported that the boundary diameter where maturation starts was $20.8,26.5,42.5$, and $48.8 \mathrm{~cm}$ in 11-years-old Acacia mangium, $A$. auriculiformis and E. globulus, and 14-years-old E. grandis, respectively. The age which the maturation started before at age 11 for A. mangium, A. auriculiformis and E. globulus, and 14 for $E$. grandis, while the maturation age was not determined exactly (Kojima et al., 2009a).

As shown in Figure 2, the basic density and compressive strength were stable greater than $6 \mathrm{~cm}$ from the pith, which suggests that E. camaldulensis might start to produce wood with stable properties, such as mature wood, greater than $6 \mathrm{~cm}$ from the pith. Using the logistic regression equation of the diameter at breast height obtained in the present study (Figure 1), we estimated the tree age at which the production of stable wood properties began. The results indicated that the diameter at breast height reached a radius of $6 \mathrm{~cm}$ at 5.5 years old, which suggests that wood with stable properties is produced after age 5.5 years. These wood properties stabilized before reaching the maximum CAI and MAI (Figure 1). In general, wood with stable properties is favorable for solid wood. Thus, a prolonged rotation age in E. camaldulensis trees might result in the production of wood with good solid wood properties. 
Relationships among measured properties

In the present study, no significant correlations were observed between the growth characteristics and wood properties (Table 3). The effects of the growth rate on wood properties in Eucalyptus species have been reported by many researchers (Bamber et al., 1982; Ohbayashi and Shiokura, 1990; Dickson et al., 2003; Kojima et al., 2009a,b; Kuramochi et al., 2014; Wahyudi et al., 2015; Prasetyo et al., 2017). Bamber et al. (1982) reported that no differences in the basic density were found between fast- and normally-grown trees in 2.5-year-old E. grandis trees in Australia. For 14-year-old E. grandis trees, the lateral growth rate did not significantly correlate with the longitudinal released strain of the growth stress and air-dry density (Kojima et al., 2009b). Similar results between the growth rates and wood properties were found in 25-year-old E. dunnii trees (Dickson et al., 2003), 26-year-old E. alba trees (Wahyudi et al., 2015), and 9-year-old E. pellita trees (Prasetyo et al., 2017). Ishiguri et al. (2017) reported that no significant correlation was found between the diameter at breast height and solid wood properties in 4-year-old E. camaldulensis trees at the progeny test site. In contrast, significant positive correlations were found between the diameter at breast height and stress-wave velocity of the stem (Ishiguri et al., 2013). From the results obtained in the present study and previous studies, E. camaldulensis families with superior growth characteristics can be selected for solid wood without negative effects on the wood properties.

Significant positive correlations were only found in the compressive strength between the inner and outer wood (Figure 3), which indicates that trees with greater compressive strength in the inner wood also tend to have greater compressive strength in the outer wood. Thus, early selection of $E$. camaldulensis families can be conducted using the compressive strength in the early growth stage. In contrast, no significant correlation was obtained in the basic density between the inner and outer wood, which suggests that the basic density of E. camaldulensis trees should be evaluated in aged trees.

\section{Among-family variations and repeatability}

Many researchers have estimated the narrow-sense heritability and/or broad-sense heritability (repeatability) of the growth characteristics and wood properties in Eucalyptus species (Kien et al., 2010; Blackburn et al., 2010; Yodnam et al., 2010; Wu et al., 2013). A total of 172 E. camaldulensis clones aged 3 to 5 were tested in three clonal tests in Vietnam, and the clonal repeatability for each site was $0.42,0.26$, and 0.41 for the diameter at breast height, $0.42,0.22$, and 0.39 for the height, and $0.78,0.71$, and 0.77 for the basic density (Kien et al., 2010). In E. urophylla clones growing in southern China, the repeatability of the diameter at breast height and height at an approximate age of 6 was 0.43 and 0.46 , respectively, and that of the stress-wave velocity of the stem and the basic density at age 8 were 0.47 and 0.51 , respectively (Wu et al., 2013). The repeatability values in this study were equal to or less than those in other Eucalyptus species clones (Kien et al., 2010; Wu et al., 2013). In addition, the clonal repeatability values of the wood properties were equal to or greater than those of the growth characteristics. In this study, the repeatability values were also observed in the stress-wave velocity and basic density and were greater than those of the growth characteristics (Table 2), which suggests that genetic factors influenced these wood properties much more than the growth characteristics. In contrast, surfacereleased strain and compressive strength parallel to the grain values showed less repeatability. Therefore, with a few exceptions, the solid wood properties of aged E. camaldulensis trees would be improved by the selection of superior growth families.

Lima et al. (2004) examined microfibril angle in the $S_{2}$ layer in inner, intermediate, and outer positions by polarized light microscopy for 8 years old E. grandis $\times E$. urophylla clones in Brazil. They reported that broad-sense heritability of microfibril angle of intermediate position was the highest, following outer and inner positions. These results suggested that genetic control might be different at different radial positions in this species. In the present study, the family variance of basic density and compressive strength were higher in the outer wood compared to the inner wood, whereas the residual variance components in the outer wood were lower than those in the inner wood (Table 4). These results indicate that the wood properties of the outer wood were largely affected by genetic factors, whereas the wood properties of the inner wood were weakly affected by genetic factors. Based on the results of this study, the selection of superior families for solid wood production from E. camaldulensis trees should be conducted with the outer wood of aged trees.

\section{Acknowledgements}

We thank the staff and students of the Faculty of Forestry of Kasetsart University, the Forestry and Forest Products Research Institute, and the School of Agriculture at Utsunomiya University for their help in field sampling and the laboratory experiments.

\section{References}

Aiso-Sanada H, Ishiguri F, Diloksumpun S, Nezu I, Tanabe J, Ohshima J, Yokota S (2019) Effects of thinning on anatomical characteristics and wood properties of 12-year-old Eucalyptus camaldulensis trees planted in Thailand. Tropics 28: 67-73. https://doi.org/10.3759/tropics.MS19-04

Bamber RK, Horne R, Graham-Higgs A (1982) Effect of fast growth on the wood properties of Eucalyptus grandis. Australian Forestry Research 12: 163-167

Bao FC, Jiang ZH, Jiang XM, Lu XX, Luo XQ, Zhang SY (2001) Differences in wood properties between juvenile wood and mature wood in 10 species grown in China. Wood Science and Technology 35: 363-375. https://doi.org/10.1007/s002260100099

Blackburn D, Hamilton M, Harwood C, Innes T, Potts B, Williams D (2010) Stiffness and checking of Eucalyptus nitens sawn boards: genetic variation and potential for genetic improvement. Tree Genetics \& Genomes 6: 757-765. https://doi.org/10.1007/s11295-010-0289-7 
Butcher PA, McDonald MW, Bell JC (2009) Congruence between environmental parameters, morphology and genetic structure in Australia's most widely distributed eucalypt, Eucalyptus camaldulensis. Tree Genetics and Genomes 5: 189-210. https://doi.org/10.1007/s11295-008-0169-6

Dickson RL, Raymond CA, Joe W, Wilkinson CA (2003) Segregation of Eucalyptus dunnii logs using acoustics. Forest Ecology and Management 179: 243-251. https://doi.org/10.1016/S0378-1127(02)00519-4

Hillis WE, Brown AG (1984) Eucalyptus for wood production. Sydney: Academic Press, 434 p, ISBN 0123487625

Hirohashi A, Kojima M, Yoshida M, Yamamoto H, Watanabe Y, Inoue H, Kamoda S (2012) Wood properties of 6 fast-growing Eucalyptus species grown in Japan. Mokuzai Gakkaishi 58: 339-346. https://doi.org/10.2488/jwrs.58.339 (in Japanese with English summary)

Honjo K, Furukawa I, Sahri MH (2005) Radial variation of fiber length increment in Acacia mangium. IAWA Journal 26: 339-352. https://doi.org/10.1163/22941932-90000119

Ishiguri F, Takeuchi M, Makino K, Wahyudi I, Takashima Y, lizuka K, Yokota S, Yoshizawa N (2012) Cell morphology and wood properties of Shorea acuminatissima planted in Indonesia. IAWA Journal 33: 25-38. https://doi.org/10.1163/22941932-90000077

Ishiguri F, Diloksumpun S, Tanabe J, lizuka K, Yokota S (2013) Stress-wave velocity of trees and dynamic Young's modulus of logs of 4-year-old Eucalyptus camaldulensis trees selected for pulpwood production in Thailand. Journal of Wood Science 59: 506-511. https://doi.org/10.1007/s10086-013-1363-1

Ishiguri F, Diloksumpun S, Tanabe J, Ohshima J, lizuka K, Yokota S (2017) Among-family variations of solid wood properties in 4-year-old Eucalyptus camaldulensis trees selected for pulpwood production in Thailand. International Wood Products Journal 8: 36-40. https://doi.org/10.1080/20426445.2016.1261528

Ishizuka K (1996) Eucalyptus camaldulensis Dehnh. In: Mori T, Ikeda S, Sakurai S, Ishizuka K, Ohta S, Asakawa K (eds.) Silvics of Tropical Trees Vol. 1. Tokyo: Japan International Forestry Promotion \& Cooperation Center, pp 200-208 (in Japanese)

Iwasaki M, Saka S, Toma T, Hayashi T, Matsumura J, Murata K (2012) Fast growing trees, Plantation and Utilization. Otsu: Kaiseisha-Press, 259 p, ISBN9784860992675 (in Japanese)

Jorge F, Quilhó T, Pereira H (2000) Variability of fibre length in wood and bark in Eucalyptus globulus. IAWA Journal 21: 41-48. https://doi.org/10.1163/22941932-90000235

Kamo K, Kiatvuttinon B, Viriyabuncha C, Kuerkool P (1990) Estimation of stem and stand volume of Eucalyptus camaldulensis. Thai Journal of Forestry 9: 129-138

Kien ND, Jansson G, Harwood C, Almqvist C (2010) Clonal variation and genotype by environment interactions in growth and wood density in Eucalyptus camaldulensis at three contrasting sites in Vietnam. Silvae Genetica 59: 1728. https://doi.org/10.1515/sg-2010-0003

Kojima M, Yamamoto H, Yoshida M, Ojio Y, Okumura K (2009a) Maturation property of fast-growing hardwood plantation species: A view of fiber length. Forest Ecology and Management 257: 15-22. https://doi.org/10.1016/j.foreco.2008.08.012

Kojima M, Yamamoto H, Okumura K, Ojio Y, Yoshida M, Okuyama T, Ona T, Matsune K, Nakamura K, Ide Y, Marsoem SN, Sahri MH, Hadi YS (2009b) Effect of the lateral growth rate on wood properties in fast-growing hardwood species. Journal of Wood Science 55: 417-424. https://doi.org/10.1007/s10086-009-1057-x

Kuramochi U, Aiso H, Diloksumpun S, Tanabe J, Ohshima J, Ishiguri F, Takashima Y, lizuka K, Yokota S, Aizawa M, Ohkubo T (2014) Among-family variation of wood properties relating to pulp qualities in 5-year-old Eucalyptus camaldulensis planted in the northeastern region of Thailand. Forest Genetics and Tree Breeding 3: 146-152 (in Japanese with English summary)

Liao CY, Podrazsky VV, Liu GB (2003) Diameter and height growth analysis for individual white pine trees in the area of Kostelec nad Černými lesy. Journal of Forest Research 49: 544-551. https://doi.org/10.17221/4723-JFS

Lima JT, Breese MC, Cahalan CM (2004) Variation in microfibril angle in Eucalyptus clones. Holzforschung 58: 160-166. https://doi.org/10.1515/HF.2004.024

Matsumoto K, Ishiguri F, lizuka K, Yokota S, Yoshizawa N (2008) Evaluation of bending and compression strength of wood using Fractometer. Wood Industry 63: 358-363 (in Japanese with English summary)
Nakagawa S, Schielzeth H (2010) Repeatability for Gaussian and non-Gaussian data: a practical guide for biologists. Biological Reviews 85: 935-956. https://doi.org/10.1111/j.1469-185X.2010.00141.x

Ohbayashi H, Shiokura T (1990) Wood anatomical characteristics and specific gravity of fast-growing tropical tree species in relation to growth rates. Mokuzai Gakkaishi 36: 889-893

Okuyama T, Sasaki Y, Kikata Y, Kawai N (1981) The seasonal change in growth stress in the tree trunk. Mokuzai Gakkaishi 27: 350-355

Pinyopusarerk K, Doran JC, Williams ER, Wasuwanich P (1996) Variation in growth of Eucalyptus camaldulensis provenances in Thailand. Forest Ecology and Management 87: 63-73. https://doi.org/10.1016/S0378-1127(96)03835-2

Pohjonen V, Pukkala T (1994) Optimum rotation for Eucalyptus camaldulensis Dehnh. in Northeast Thailand. Thai Journal of Forestry 13: 29-37

Prasetyo A, Aiso H, Ishiguri F, Wahyudi I, Wijaya IPG, Ohshima J, Yokota S (2017) Variations on growth characteristics and wood properties of three Eucalyptus species planted for pulpwood in Indonesia. Tropics 26: 59-69. https://doi.org/10.3759/tropics.MS16-15

Prasetyo A, Aiso-Sanada H, Ishiguri F, Wahyudi I, Wijaya IPG, Ohshima J, Yokota S (2019) Variations in anatomical characteristics and predicted paper quality of three Eucalyptus species planted in Indonesia. Wood Science and Technology 53: 1409-1423. https://doi.org/10.1007/s00226-019-01137-5

R Development Core Team (2017) R: A language and environment for statistical computing. R Foundation for Statistical Computing, Vienna, Austria. https://www.R-project.org/.Downloaded in 1 May 2018

Sasaki Y, Okuyama T, Kikata Y (1978) The evolution process of the growth stress in the tree: The surface stresses on the tree. Mokuzai Gakkaishi 24: 149-157

Sungtong T, Diloksumpun S (2011) Variations in physiological characteristics of different Eucalyptus camaldulensis Dehnh. half-sib families. Thai Journal of Forestry 30: 1-13 (in Thai with English summary)

Thomson L, Doran J, Clarke B (2018) Trees for life in Oceania: conservation and utilisation of genetic diversity. Canberrra: ACIAR. 278 p, ISBN 20183361036

Veenin T, Fujita M, Nobuchi T, Siripatanadilok S (2005) Radial variations of anatomical characteristics and specific gravity in Eucalyptus camaldulensis clones. IAWA Journal 26: 353-361. https://doi.org/10.1163/22941932-90000120

Wahyudi I, Ishiguri F, Makino K, Tanabe J, Tan L, Tuhumury A, lizuka K, Yokota S (2015) Growth characteristics and wood properties of 26-year-old Eucalyptus alba planted in Indonesia. International Wood Products Journal 6: 84-88. https://doi.org/10.1179/2042645315Y.00000000034

Wilkes J (1984) The influence of rate of growth on the density and heartwood extractives content of eucalypt species. Wood Science and Technology 18: 113-120. https://doi.org/10.1007/BF00350470

Williams ER, Matheson AC, Harwood CE (2002) Experimental Design and Analysis for Tree Improvement, 2nd Ed. Melbourne: CSIRO. 220 p, ISBN 0643062599. https://doi.org/10.1071/9780643090132

Wu S, Xu J, Li G, Lu Z, Han C, Hu Y, Hu X (2013) Genetic variation and genetic gain in growth traits, stem-branch characteristics and wood properties and their relationships to Eucalyptus urophylla clones. Silvae Genetica 62: 218231. https://doi.org/10.1515/sg-2013-0027

Yodnam S, Wachrinrat C, Diloksumpun S (2010) Progeny test of the second generation Eucalyptus camaldulensis Dehnh. at Wang Nam Khiao Forestry Student Training Station. Thai Journal of Forestry 29: 37-49 (in Thai with English summary) 